From Psychiatric Patient to Citizen 


\section{From Psychiatric \\ Patient to Citizen}

Overcoming Discrimination and Social Exclusion

Liz Sayce 
First published in Great Britain 2000 by

MACMILLAN PRESS LTD

Houndmills, Basingstoke, Hampshire RG21 6XS and London

Companies and representatives throughout the world

A catalogue record for this book is available from the British Library.

ISBN 978-0-333-69890-7 ISBN 978-1-349-27833-6 (eBook)

DOI 10.1007/978-1-349-27833-6

First published in the United States of America 2000 by

ST. MARTIN'S PRESS, INC.,

Scholarly and Reference Division,

175 Fifth Avenue, New York, N.Y. 10010

ISBN 978-0-312-22733-3

Library of Congress Cataloging-in-Publication Data

Sayce, Liz.

From psychiatric patient to citizen : overcoming discrimination

and social exclusion / Liz Sayce.

p. $\mathrm{cm}$.

Includes bibliographical references and index.

ISBN 978-0-312-22733-3

1. Mental illness-Public opinion. 2. Discrimination against the mentally ill. 3. Stigma (Social psychology) 4. Mental health laws.

I. Title.

RC455.2.P85S29 1999

$362.2^{\prime} 0422-\mathrm{dc} 21$

99-16944

CIP

(C) Liz Sayce 2000

All rights reserved. No reproduction, copy or transmission of this publication may be made without written permission.

No paragraph of this publication may be reproduced, copied or transmitted save with written permission or in accordance with the provisions of the Copyright, Designs and Patents Act 1988, or under the terms of any licence permitting limited copying issued by the Copyright Licensing Agency, 90 Tottenham Court Road, London W1P 0LP.

Any person who does any unauthorised act in relation to this publication may be liable to criminal prosecution and civil claims for damages.

The author has asserted her right to be identified as the author of this work in accordance with the Copyright, Designs and Patents Act 1988.

This book is printed on paper suitable for recycling and made from fully managed and sustained forest sources.

$\begin{array}{llllllllll}10 & 9 & 8 & 7 & 6 & 5 & 4 & 3 & 2 & 1\end{array}$

$\begin{array}{llllllllll}09 & 08 & 07 & 06 & 05 & 04 & 03 & 02 & 01 & 00\end{array}$ 


\section{Contents}

List of Abbreviations vi vi

Acknowledgements vii

$\begin{array}{ll}\text { Introduction } & \mathbf{1}\end{array}$

1 A Dream of Inclusion 18

2 Future Dreams, Future Nightmares 38

3 The Illusion of Citizenship $\quad 56$

4 Models of Anti-discrimination Work: The Brain Disease Model 84

5 The Individual Growth Model 100

6 The Libertarian Model 116

7 The Disability Inclusion Model: No to Shame 129

8 The Potential of Anti-discrimination Law 145

9 The Limits of the Law 166

10 Public Debate, Political Action 186

11 Influencing Public Opinion 205

12 Making Inclusion Happen at the Grassroots 229

$\begin{array}{ll}\text { Conclusion } & 245\end{array}$

$\begin{array}{lr}\text { References } & 249\end{array}$

$\begin{array}{ll}\text { Index } & 269\end{array}$ 


\section{List of Abbreviations}

AA Alcoholics Anonymous

ACAS Advisory, Conciliation and Arbitration Service (UK)

ADA Americans with Disabilities Act 1990

APA American Psychiatric Association

ASA Advertising Standards Authority (UK)

DBTAC Disability and Business Technical Assistance Center (US)

DDA Disability Discrimination Act 1995 (UK)

DfEE Department for Education and Employment (UK)

DoJ Department of Justice (US)

DREDF Disability Rights Education and Defense Fund (US)

DSM Diagnostic and Statistical Manual (US)

DSS Department of Social Security (UK)

EAP Employee Assistance Program (US)

ECT Electro-convulsive therapy

EEOC Equal Employment Opportunity Commission (US)

FBI Federal Bureau of Investigation (US)

HEA Health Education Authority (UK)

HUD Housing and Urban Development Department (US)

INS Immigration and Naturalization Service (US)

JAN Job Accommodation Network (US)

MRI Magnetic Resonance Imaging

NAMI National Alliance for the Mentally Ill (US)

NARPA National Association of Rights Protection and Advocacy (US)

NHS National Health Service (UK)

Nimby Not in My Back Yard

NSF National Schizophrenia Fellowship (UK)

SAMHSA Substance Abuse and Mental Health Services

Administration (US)

SSI Supplemental Security Income

SANE Schizophrenia: A National Emergency (UK)

WHO World Health Organization 


\section{Acknowledgements}

I would like to thank all the user/survivors of mental health services, in the US and UK, who have generously shared their thoughts with me, and to acknowledge everyone who has spoken openly, in any context, about their experiences of distress, depression or madness. Without people prepared to be open, often at considerable risk, there would be no movement for challenging discrimination on mental health grounds.

I am enormously grateful to all the user/survivor and disability leaders, policy makers, advocates, lawyers, mental health professionals and academics, in the US, the UK and beyond, who have shared their views and time with me and in many cases gone to considerable trouble to assist my research.

Among those who have contributed directly to this work, I would like to mention Len Rubenstein, previously Executive Director of the Bazelon Center for Mental Health Law, who guided me through my Harkness Fellowship research in the US; the Bazelon Center for its tremendous hospitality; Vida Field, Judi Chamberlin, Michael Allen and Len Rubenstein for invaluable advice on different drafts; the Harkness Fellowships for making this work possible; my ex-colleagues at Mind for stimulating and creative debates; my mother, Olive Sayce, for heroic assistance with proofreading; and Jane Elliott for kindly translating a Chinese disability discrimination law to satisfy my curiosity. The vicws expressed here are, however, mine alone.

This book is partly about how to break down barriers to enable user/survivors to be part of different 'communities'. At best, communities can provide us with many things, including personal identity, a common purpose with others, support, friendship, feedback - and a sense that we belong in a social world. I am part of a generation of women who have built networks of friends, replacing older geographical communities. I would like to thank my family and my 'community'. 
The author and publishers wish to thank the following for permission to use copyright material:

Australian National Mental Health Strategy Community Awareness Program, an initiative of the Australian Commonwealth Department of Health and Aged Care for the mental health poster (The defence didn't stop him. Neither did mental illness) reproduced in Chapter 11.

Brown Brothers for the Ellis Island illustrations in Chapter 3.

Gary Brookins for his cartoon, depicting a service user as an axeman, first published in the Richmond Times-Dispatch, Virginia, May 1997, and reproduced in Chapter 10.

Health Education Authority for the Mind postcards reproduced in Chapter 11.

Every effort has been made to trace all the copyright holders but if any have been inadvertently overlooked the publishers will be pleased to make the necessary arrangements at the first opportunity. 